\title{
Effects of Different Levels of Organomineral Fertilizer on the Yield and Yield Components of Rice (Oryza Sativa L.) In A Coastal Flood Plain Soil, Nigeria.
}

\author{
Egbuchua, C. N. and Enujeke, E. C \\ Department of Agronomy Delta State University, Asaba Campus Asaba, Delta State, Nigeria
}

\begin{abstract}
Field experiments were carried out during the 2011/2012 cropping seasons in the flood plain soil of the Teaching and Research Farms of the Delta State University, Asaba Campus, Asaba. The aim was to evaluate the effects of organomineral fertilizer on the yield and yield components of rice. The treatments were four levels of organomineral fertilizer (poultry manure fortified with ammonium nitrate) and a control at the rates of 0 , 2.5, 5.0, 7.0 and 10 tha $a^{-l}$. The experiment was laid out in a randomized complete block design replicated three times. Data were collected at the $4^{\text {th }}, 8^{\text {th }}, 12^{\text {th }}$ and 16 th weeks after planting (WAP) on plant height, total leaf area, number of tillers, straw and grain yield, 1000 grain weight and harvest index. Data collected were subjected to analysis of variance and significant differences separated using student-Newman-Keals test. The results showed that 10 tha ${ }^{-1}$ treatment application gave the highest values in plant height $(75.45 \mathrm{~cm})$, leaf area $(374.24)$, straw and grain yield 534.20 and $625.03 \mathrm{kgha}^{-1}$ and 1000 grain weight $42.7 \mathrm{~g} / \mathrm{ha}^{-1}$. There was a Synergistic affects of organomineral fertilizer in all growth and yield parameters evaluated.
\end{abstract}

Keywords: Effects, different levels, organomineral fertilizer, Rice.

\section{Introduction}

Rice (Oryza sativa L.) is an important cereal crop of the gramineae family and a major staple food that is widely consumed all over the world irrespective of race, religion and political association (Ohajianya and Onyenweaku, 2002). The crop is very unique among the World's major food crops by virtue of the extent of its uses as livestock feeds, raw material in many breweries and pharmaceutical industries and currently as a source of bio-fuel (Hirst, 2006 and Encyclopedia botanical, 2009). The crop by virtue of its genetic constituents is usually cultivated in shallow flood and at the opposite extreme, as an upland cereal (Kebbah et al, 2003). In most tropical farming communities, the use of inorganic fertilizers to boast yield of rice cannot be underestimated as they have been found to increase crop performance as well as the chemical properties of soils (Ojeniyi, 2000). However, it's continuous use could cause nutrient in-balance and soil acidity (Doran et al, 2008). Against all these, it has been suggested that organic manures should be used in rice production as they are known to increase yield (Olayinka, 1990). Although, crop production across the ages depended mainly on organic manures such as poultry droppings; cattle dung; farm yard manure; pig manure and recently bio-fertilizers such as Azolla and Mycorrihiza. These manure sources however, are associated with problems relating to inadequate availability, low quality depending on the type, transportation and handling problems, high C:N ratio, heavy metal pollution and slow nutrient release (Ayeni et al, 2010). The single use of either organic or inorganic fertilizers in recent years have not really met the expected impact in boasting crop yield to cope with the geometric demand hence, integrated nutrient supply have been advocated by the Food and Agricultural Organization of the United Nation (Olowokere, 2004). In view of this, the combined use of chemical fertilizers and inorganic manures (organomineral fertilizer) has been suggested (FAO, 2000).

Organomineral fertilizer indeed is a low input technology of improving the poor nutritional status of tropical soils for sustainable crop production. It combines the good attributes of both sources to enhance yield. In many parts of the World, emphasizes are greatly shifting from the simple use of either organic or inorganic fertilizers to combined use. Now that Nigeria is facing the greatest challenges of food insecurity resulting from the recent flooding that devastated some parts of the country coupled with the fast declining productivity of our soils. It becomes imperative that the combined use of organic and inorganic fertilizers (organomineral fertilizer) should be encouraged and introduced to our numerous farmers in order to achieve their yield expectancy and maximum benefit from their introduction. Current researches on organomineral fertilizer have shown better yield performances than the single use of them. (Olowokere, 2004, Ojeniyi et al., 2009; Olatunji and Ayuba 2011).

Because of the importance of rice as one of the major staple food crop and the Federal Government of Nigeria desire to expand the scope of production across ecological zones, it is therefore the objective of this study to evaluate the responses of rice to different levels of organomineral fertilizers. 


\section{Description of the study area}

\section{Materials And Methods}

The study was conducted in the riverflood plain of the Teaching and Research Farms of the Delta State University, Anwai, Asaba Campus during the 2011/2012 cropping season. The experimental site is located within latitude $06^{\circ} 14^{\prime} \mathrm{N}$ and longitude $06^{\circ} 49^{\prime} \mathrm{E}$ of the equator and lies significantly in the tropical rainforest zone. The rainfall pattern is bimodal with peaks in July and September and a mean annual of $1,650 \mathrm{~mm}$. The mean temperature is about $37.3^{\circ} \mathrm{C}$ and a relative humidity of $73.2 \%$. The land area is relatively flat (1-2\%) slope gradient and influenced seriously by seasonal flooding due to its proximity to River Niger towards the end of the year.

By nature of its geomorphological setting, the study area overlies the ancient metamorphic crystalline basement complex formation which are considerably more acid than base (Egbuchua, 2012). They are generally gneisses and pegmatites that gave rise to coarse-textured soils that are deficient in dark ferro-magnesian minerals.

Land use is based on rainfed agriculture and the vegetation is typically of rainforest origin with different species of sedges and grasses.

\section{Experimental layout/Soil sampling and characterization}

The field used for the experiment measuring $136 \times 90 \mathrm{~m}$ was prepared and marked out using basin Formation according to the experimental layout. Initial soil samples were randomly taken with an auger from the field plot at $0-20 \mathrm{~cm}$ depth. A composite sample was obtained, air-dried, crushed and sieved through a $2 \mathrm{~mm}$ sieve mesh. Sub-samples were taken for characterization of some important physico-chemical properties. The parameters evaluated include the particle size distribution which was determined by hydrometer method (Gee and Bauder, 1986). Soil pH was determined using Pye unicam model $290 \mathrm{M} \mathrm{K} 2 \mathrm{pH}$ meter in a 1:2.5 soil/water suspension. Organic carbon was determined by Walkley-Black dichromate wet oxidation method (Nelson and Sommer, 1982). Total nitrogen was determined by micro-Kjeldahl technique as described by Bremmer and Mulvaney (1982). Available phosphorus was determined by Bray No. 1 method as described in IITA (1982) laboratory manuals. Cation exchange capacity (CEC) was determined using Ammonia acetate saturation method (Rhoades, 1982).

\section{Treatments and Experimental design}

The treatments consisted of four levels of organomineral fertilizer and a control at 0, 2.5, 5.0, 7.5 and 10 tha. The organomineral fertilizer was derived from poultry manure and fortified with ammonium sulphate which has $33 \%$ nitrogen content. The chemical content of the poultry manure as analysed were: $\mathrm{pH}=5.8$, organic carbon $=17.7 \mathrm{gkg}_{-}{ }^{1}, \mathrm{~N}=19.3 \mathrm{gkg}_{-}{ }^{1} \mathrm{P}=28.9 \mathrm{gkg}_{-}{ }^{1} \mathrm{~K}=14.7 \mathrm{gkg}^{-1}, \mathrm{Ca}=21.1 \mathrm{gkg}_{-}{ }^{1} \mathrm{Mg}=$ $3.50 \mathrm{gkg}_{-}{ }^{1} \mathrm{Zn}=1.10 \mathrm{gkg}^{-1}$ and $\mathrm{Mn}=0.64 \mathrm{gkg}_{-}{ }^{1}$. The ' experiment was laid out in a randomized complete block design replicated three times. Organomineral fertilizer was applied in three -split applications one week before planting using incorporation method, and at $5^{\text {th }}$ and $8^{\text {th }}$ weeks after planting (WAP) by banding at the rates of $0,2.5,5.0,7.5$ and 10 tha $^{-1}$. Growth and yield data were taken at $4,8,12$ and $16^{\text {th }}$ weeks after planting. Parameters evaluated were plant height, total leaf area, number of tillers, straw and grain yield, 1000 grain weight and harvest index.

\section{Statistical analysis}

All data collected were subjected to analysis of variance (ANOVA) using SAS (2003) statistical package. Where F-values were found to be significant, treatments were separated using student NewmanKeals test.

\section{Pre-planting soil analysis}

\section{Results And Discussion}

The results of the initial physico-chemical properties of the soil used for the experiments (Table 1) showed that the soil for the study was a loamy sand in texture with $83.70 \%$ total sand, $12.90 \%$, silt and $3.30 \%$ clay contents. The soil $\mathrm{pH}$ was strongly acidic with a $\mathrm{pH}$ value of 5.5 . The organic carbon $\left(15.6 \mathrm{gkg}_{-}{ }^{1}\right)$; total

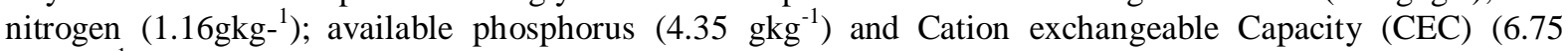
$\mathrm{cmolkg}^{-1}$ ) are all rated low depicting the low fertility status of the soil. 
Table 1:Pre planting soil analysis of the study area

\begin{tabular}{ll} 
Soil properties & $\underline{\text { Values }}$ \\
\hline Particle Size distribution $(\%)$ & 83.70 \\
Sand & 12.00 \\
Silt & 4.30 \\
Clay & Loamysand \\
Textural class & 5.5 \\
$\mathrm{pH}\left(\mathrm{H}_{2} \mathrm{O}\right)$ & 15.6 \\
Organic carbon $\left(\mathrm{gkg}^{-1}\right)$ & 1.16 \\
Total nitrogen $\left(\mathrm{gkg}^{-1}\right)$ & 4.35 \\
Available phosphorus $\left(\mathrm{mgkg}^{-1}\right)$ & 6.75 \\
Cation exchange capacity $\left(\mathrm{cmolkg}^{-1}\right)$ &
\end{tabular}

\section{Effects on Growth characters}

Plant height

There was a significant $(\mathrm{P}<0.005)$ effects on plant height of rice. Plant height was found to increase progressively with increase in various rates of treatment application compared to the control (Table 2). The highest plant height of $75.45 \mathrm{~cm}$ was obtained at $16^{\text {th }}$ week after planting at 10 tha $^{-1}$ treatment application. This was followed by $63.10 \mathrm{~cm}$ at $7.5 \mathrm{tha}^{-1}$ and $62.75 \mathrm{~cm}$ at $5.0 \mathrm{tha}^{-1}$ rates of application. These were statistical different from the control where $48.94 \mathrm{~cm}$ plant height was obtained at $16^{\text {th }}$ weeks after planting (WAP).

Table 2: Effects of different levels of organomineral fertilizer on plant height $(\mathrm{cm})$ at rice (Oryza sativa L.)

\begin{tabular}{ccccc}
\hline $\begin{array}{c}\text { Treatment } \\
\text { (t/ha) }\end{array}$ & \multicolumn{3}{c}{ Weeks after planting } \\
\hline & $\mathbf{4}$ & $\mathbf{8}$ & $\mathbf{1 2}$ & $\mathbf{1 6}$ \\
\hline 0 & $22.13^{\mathrm{a}}$ & $30.37^{\mathrm{a}}$ & $45.75^{\mathrm{a}}$ & $48.94^{\mathrm{a}}$ \\
2.5 & $22.15^{\mathrm{a}}$ & $30.41^{\mathrm{a}}$ & $45.85^{\mathrm{a}}$ & $49.10^{\mathrm{a}}$ \\
5.0 & $22.7^{\mathrm{a}}$ & $35.45^{\mathrm{b}}$ & $58.72^{\mathrm{b}}$ & $62.75^{\mathrm{b}}$ \\
7.5 & $22.17^{\mathrm{a}}$ & $35.75^{\mathrm{b}}$ & $58.85^{\mathrm{b}}$ & $63.10^{\mathrm{b}}$ \\
10.0 & $22.21^{\mathrm{a}}$ & $45.38^{\mathrm{c}}$ & $67.74^{\mathrm{c}}$ & $75.45^{\mathrm{d}}$ \\
\hline
\end{tabular}

Means in the same column with similar subscript letters are not significantly different $(\mathrm{F}-\mathrm{LSD}=0.005 \%)$

\section{Total Leaf area}

Effects on total leaf area (Table 3) showed that there was a significant influence of treatments at various rates up to the $16^{\text {th }}$ week after planting where the widest leaf area of $374.24 \mathrm{~cm}$ at 10.0 tha $^{-1}$ rate of treatment application was obtained. The control experiment produced the least leaf area of $54.37 \mathrm{~cm}$. The significant $(\mathrm{P}<0.05)$ different of plants that received treatments over control confirmed the work of Schippers (2000) who reported that organomineral fertilizer are very useful in promoting plant height and vegetative growth of plant by producing large leaf areas.

Table 3: Effects of different levels of organomineral fertilizer on leaf area $\left(\mathrm{cm}^{3}\right)$ at rice $($ Oryza sativa $\mathbf{L}$.

\begin{tabular}{ccccc}
\hline $\begin{array}{c}\text { Treatment } \\
\text { (t/ha) }\end{array}$ & \multicolumn{4}{c}{ Weeks after planting } \\
\hline & $\mathbf{4}$ & $\mathbf{8}$ & $\mathbf{1 2}$ & $\mathbf{1 6}$ \\
\hline 0 & $13.28^{\mathrm{a}}$ & $25.76^{\mathrm{a}}$ & $45.75^{\mathrm{a}}$ & $54.37^{\mathrm{a}}$ \\
2.5 & $13.32^{\mathrm{a}}$ & $25.95^{\mathrm{a}}$ & $46.15^{\mathrm{a}}$ & $72.45^{\mathrm{a}}$ \\
5.0 & $13.35^{\mathrm{a}}$ & $35.18^{\mathrm{b}}$ & $75.30^{\mathrm{b}}$ & $117.32^{\mathrm{c}}$ \\
7.5 & $13.41^{\mathrm{a}}$ & $45.28^{\mathrm{c}}$ & $110.35^{\mathrm{c}}$ & $215.38^{\mathrm{d}}$ \\
10.0 & $13.45^{\mathrm{a}}$ & $65.39^{\mathrm{d}}$ & $185.31^{\mathrm{d}}$ & $374.24^{\mathrm{e}}$ \\
\hline
\end{tabular}

Means in the same column with similar subscript letters are not significantly different (F-LSD $=0.005 \%$ )

\section{Number of tillers}

The effects of treatments on the number of tillers (Table 4) showed that no tillers were observed at the $4^{\text {th }}$ week after planting with increase rates of treatment application. Plants that received 7.5 tha $^{-1}$ treatments produced the highest number of tillers of 12.35 . This was significantly different $(\mathrm{P}<0.05)$ from plants with no treatment application. 
Table 4: Effects of different levels of organomineral fertilizer on number of tillers at rice (Oryza sativa L.)

\begin{tabular}{ccccc}
\hline $\begin{array}{c}\text { Treatment } \\
\text { (t/ha) }\end{array}$ & \multicolumn{3}{c}{ Weeks after planting } \\
\hline & $\mathbf{4}$ & $\mathbf{8}$ & $\mathbf{1 2}$ & $\mathbf{1 6}$ \\
\hline 0 & - & $2.25^{\mathrm{a}}$ & $4.23^{\mathrm{a}}$ & $4.75^{\mathrm{a}}$ \\
2.5 & - & $2.75^{\mathrm{a}}$ & $7.71^{\mathrm{b}}$ & $9.20^{\mathrm{b}}$ \\
5.0 & - & $4.73^{\mathrm{b}}$ & $9.25^{\mathrm{c}}$ & $10.34^{\mathrm{c}}$ \\
7.5 & - & $5.84^{\mathrm{c}}$ & $11.85^{\mathrm{d}}$ & $12.35^{\mathrm{d}}$ \\
10.0 & - & $4.87^{\mathrm{b}}$ & $9.15^{\mathrm{c}}$ & $11.84^{\text {cd }}$ \\
\hline
\end{tabular}

Means in the same column with similar subscript letters are not significantly different $(\mathrm{F}-\mathrm{LSD}=0.005 \%)$

Straw and grain yield,

The effects on straw and grain yield were recorded at harvest (Table 5). The straw and grain yield were significantly influenced by rates of treatment application. 10 tha $^{-1}$ treatment produced $534.20 \mathrm{~kg} / \mathrm{ha}^{-1}$ straw yield and $625.03 \mathrm{~kg} / \mathrm{ha}$ grain yield when compared to $242.36 \mathrm{~kg} / \mathrm{ha}$ and $352.76 \mathrm{~kg} / \mathrm{ha}$ respectively over the control.

Table 5: Effects of different levels of organomineral fertilizer on straw grain yield of rice (Oryza sativa L.) at harvest (16 weeks after planting)

\begin{tabular}{ccc}
\hline $\begin{array}{c}\text { Treatment } \\
(\mathbf{t} / \mathbf{h a})\end{array}$ & $\begin{array}{c}\text { Straw yield } \\
\left(\mathbf{k g ~ h a}^{-1}\right)\end{array}$ & $\begin{array}{c}\text { Grain yield } \\
\left(\mathbf{k g ~ h a}^{-1}\right)\end{array}$ \\
\hline 0 & $242.36^{\mathrm{a}}$ & $352.76^{\mathrm{a}}$ \\
2.5 & $245.14^{\mathrm{a}}$ & $365.10^{\mathrm{a}}$ \\
5.0 & $321.21^{\mathrm{b}}$ & $425.34^{\mathrm{b}}$ \\
7.5 & $456.10^{\mathrm{c}}$ & $521.14^{\mathrm{c}}$ \\
10.0 & $534.20^{\mathrm{d}}$ & $625.03^{\mathrm{d}}$ \\
\hline
\end{tabular}

Means in the same column with similar subscript letters are not significantly different ( F-LSD $=0.005 \%$ )

1000 grain weight and harvest index (HI)

Table 6 showed the effects of treatment on 1000 grain weight and harvest index. There was no significant difference $(\mathrm{P}<0.05)$ on 1000 grain weight. Although, the highest 1000 grain weight of 42.71 $\mathrm{g} /$ ha was obtained at 10.0 tha $^{-1}$ rate of application, this was not statistically different from other levels of application. With respect to harvest index which is the ratio of grain yield to total dry matter yield, it was found to decrease with increase in plant biomass. Harvest index in the control plots and in plots where 2.5 tha $^{-1}$ treatment was applied was not significantly different. The same trend was observed in plots that received 5.0 and 7.5 tha $^{-1}$ treatments (Table 6). The highest harvest index of 0.43 which was significantly different from other application rates was obtained at 10 tha $^{-1}$ treatment application.

Table 6: Effects of different levels of organomineral fertilizer on 1000 grain weight and harvest index (Hi) at harvest (16 weeks after planting)

\begin{tabular}{ccc}
\hline $\begin{array}{c}\text { Treatment } \\
\text { (t/ha) }\end{array}$ & $\begin{array}{c}\mathbf{1 0 0 0} \text { grain } \\
\text { g/ha }\end{array}$ & $\begin{array}{c}\text { Harvest index } \\
(\mathbf{H i})\end{array}$ \\
\hline 0 & $26.12^{\mathrm{a}}$ & $0.32^{\mathrm{a}}$ \\
5.5 & $26.17^{\mathrm{a}}$ & $0.34^{\mathrm{a}}$ \\
7.0 & $28.25^{\mathrm{b}}$ & $0.37^{\mathrm{b}}$ \\
1.5 & $30.42^{\mathrm{c}}$ & $0.39^{\mathrm{b}}$ \\
\hline .0 & $42.71^{\mathrm{d}}$ & $0.43^{\mathrm{c}}$ \\
\hline
\end{tabular}

Means in the same column with similar subscript letters are not significantly different (F-LSD $=0.005 \%)$

\section{Discussion}

The significant $(\mathrm{P}<0.05)$ influence of organomineral fertilizer on some growth and yield components could be attributed to the synergistic effects of the treatment in rice physiological processes, restoring soil quality and increasing yield by the combination of the two nutrient sources (Brady and Weil, 1999). In some related studies, Ojeniyi et al, (2009) reported an increase in plant height, leaf area, grain yield, cob and ear weight of cereals treated with organomineral fertilizer.

Adeniyan and Ojeniyi (2003) have also reported that balanced plant nutrition and enhanced crop production are ensured with the use of organomineral fertilizer. Ande et al, (2010) have also reported better performances of maize and other cereals when treated with combined use of organic and inorganic fertilizers.

Fashola and Ogungbe (2007), Akanbi et al, (2010), Olatunji and Ayuba (2011) in their different fertilizer treatment studies on different crops, reported that crops that received the combination of organic and inorganic fertilizers (Organomineral fertilizer) performed better in all growth and yield components. They 
adduced this to the nutrient qualities of the two combinations. The higher plant height, leaf area, number of tillers, straw and grain yield obtained with organomineral fertilizer over the control could be attributed to the improvement of soil physical properties such as nutrient retention, structural stability and continual availability of major nutrients especially solubilized phosphorus coupled with possible chelation of micro nutrients by organic constituents of the organomineral fertilizer.

\section{Conclusion}

Rice is the most popular staple menu in practically all families in Nigeria and the consumption of it cuts across ethnic, religious and geographical boundaries. In the current drive by the Federal Government of Nigeria to achieve food sufficiency in rice production in 2020, improved yield could be achieved by the use of organomineral fertilizer. The results of the study showed a positive influence of organomineral fertilizer on growth and yield components of rice plant over the control. Yield parameters in terms of grain yield, 1000 grain weight and straw weight were found to be higher at all levels of treatment application than the control.

\section{References}

[1]. Adeniyan, O. N. and Ojeniyi S. O. (2003) Comparative effectiveness of different levels of poultry manure in the N.P.K. fertilizer and residual soil fertility nutrient uptake and yield of maize. Moor Journal of Agricultural Research 4(2): 191-197.

[2]. Akanbi, W. B., Illupeju, E.A.O, Togun, A. O. and Adeyeye, S. A. (2010) Effects of Nigerian commercial organic fertilizers compost and NPK on maize performance, plant and soil nutrient content. International Journal of Organic Agricultural Research and Development 1(1): 135-149.

[3]. Ayeni, L.S. Omole, T, Adeleye, E.O. and Ojeniyi, S. O. (2010). Integrated application of poultry manure and NPK fertilizer on performance of tomato in derived savanna transition zone of South-West Nigeria. Science and Nature 8(2): 50-54.

[4]. Brady, N.C. and Weil, R.R. (1999). The Nature and Properties of soil. 12 $2^{\text {t" }}$ edition Delhi, Pearson Educational Publishers.

[5]. Bremmer, J. M and Malvaney, C. S. (1982) Total nitrogen. In: Page, A. L., Miller, R. H. and Keeney, D.R. (eds). Methods of soil analysis. Part 2 Agron. 9 Madison W.I. P. 149-157.

[6]. Doran, J. W. Sarrantonia, M. Liebig, M (1996) Soil health and sustainability. Advances in Agronomy 56. No. 1 p. 25-45

[7]. *Egbuchua, C. N. (2012) Pedological characterization of some alluvial complex soils in Delta State, Nigeria. Nigerian Journal of Soil and Environmental Research 9 p. 65-70

[8]. Encyclopedia Britannica (2009)'Rice studies (home edition) Chicago, USA.

[9]. Fagbola, 0, and Ogungbe, P. W. (2007) Growth and yield response of some maize cultivars to organomineral fertilizer application in simulated degraded soil under green house conditions. Nigerian Journal of Soil Science 17:89-93.

[10]. Gee, G.W. and Bauder, J.W. (1986) Particle size analysis. In: Klute, A (ed.) Methods of soil analysis, Part 2. Chemical and microbiological properties $2^{\text {nd }}$ edition Agron. Monograph 9. Madison, W.I. USA.

[11]. Hirst, K.K. (2006) History of rice: Archaeological evidence of the history of rice http://archaeoloqy.about.com\%odidomestications/alrice.html

[12]. IITA International Institute of Tropical Agriculture. (1989) Automated and semi-automated methods for soil and plant analysis. Manual series No. 7

[13]. Kebbah, M. S. Haefele, G. O. and Fagade, S. O. (2003) Challenges and Opportunities for improving irrigated rice productivity in Nigeria. Abidjan: WARDA.

[14]. Kebbah, M. S. Haefele, S. 0. (2003) Challenges and Opportunities for improving irrigated rice productivity in Nigeria. Abidjan: WARDA.

[15]. Nelson, D.W. and Sommers, L.E. (1982) Organic carbon. In: Page, A.L.; Miller, R.H. and Keeney, D.R. (eds). Methods of soil analysis Part 2. Agron 9. Madison W.I. 538-580.

[16]. Ohajianya, D. O. and Onyenweaku, C. E. (2002) Farm size and relative efficiency in rice production in Ebonyi State, Nigeria. A profit function approach AMSE Journal France, 25(1): 28-42.

[17]. Ojeniyi S.O. Makinde, E. A. Odedina S.A. and Odedina, J. N. (2009) Effects of organomineral and NPK fertilizers on nutritional quality of Amaranthus in Lagos, Nigeria. Nigerian Journal of Soil Science 19(2) 129-134.

[18]. Ojeniyi, S. O. (2000) Effects of goat manure on soil nutrient content and Okra yield in rainforest area, Nigeria. Applied Journal of Tropical Agriculture. 51: 20-23.

[19]. Olatunji, O. and Ayuba, S. A(2011) Effects of combined application of poultry manure and NPK 20-10-10 fertilizers on soil chemical properties and yield of maize (Zea may L.). Proceedings of the $35^{\text {th }}$ Annual Conference of the Soil Science Society of Nigeria. 7 th $-11^{\text {th }}$ March, 2011, Minna, Nigeria.

[20]. Olayinka, A. (1990) Effects of poultry manure, corn straw and saw-dusts on plant growth and soil chemical properties. Ife Journal of Agriculture 12(1 and 2) 36-44.

[21]. Olowokere, F. A. (2004). Effects of different levels of poultry based organomineral fertilizer and weeding interval on the growth and yield of Okro. Proceedings of the $29^{\text {th }}$ Annual Conference of the Soil Science Society of Nigeria. 6-10 ${ }^{\text {th }}$ Dec., 2004, Abeokuta, Nigeria.

[22]. Rhoades, J.D. (1982) Cation exchange capacity. In: Page, A. L. Miller, R. H. and Keeney, D. R. (eds). Methods of Soil analysis. Part 2. Agron A. Madison W.I. P. 149-157.

[23]. SAS (2003) Statistical analytical system for linear models: A guide to the ANOVA and GLM procedures SAS Inst. Cary, N.C.

[24]. Satyanarayana, V.M. Vera-Prasad, P.V. Murphy, VRK and Books, K. J. (2002) Influence of integrated use of FYM and inorganic fertilizer on yield and yield components of irrigated lowland rice. Journal of plant nutrition 25(10): 2081-2090.

[25]. Schippers, R. R (2000) African indigenous vegetables. An overview of the cultivated species. National resources institute Walking Ford Oxio and DE UK. 